\title{
Multiple contaminations of chickens with Campylobacter, Escherichia coli and Salmonella in Yaounde (Cameroon)
}

\author{
Ariane Nzouankeu ${ }^{1,2}$, Antoinette Ngandjio $^{1}$, Guy Ejenguele ${ }^{1}$, Thomas Njine ${ }^{2}$, Marguerite Ndayo \\ Wouafo $^{1}$
}

${ }^{1}$ Pasteur Centre of Cameroon, Yaounde, Cameroon

${ }^{2}$ University of Yaounde I, Faculty of Science, Yaounde, Cameroon

\begin{abstract}
Introduction: Food-borne diseases associated with Campylobacter, Escherichia coli, and Salmonella are mainly caused by the consumption of raw or undercooked poultry meat. The objective of this study was to evaluate the prevalence of Campylobacter, Escherichia coli, and Salmonella in chickens.

Methodology: One hundred and fifty chickens collected from eight retail markets in Yaounde were examined for the presence of Campylobacter, Escherichia coli, and Salmonella using standard bacteriological procedures.

Results: Of the 150 chickens collected, 135 (90\%) were contaminated with Campylobacter (68.9\% C. coli and $31.1 \%$ C. jejuni). All the chickens were positive for E. coli. Among the 150 isolates, 17 (11.3\%) were enteropathogenic E. coli (EPEC). Additionally, 103 Salmonella strains were recovered from 90 chickens. Salmonella Enteritidis (45.6\%) and Salmonella Hadar (28.1\%) were the most frequent serotypes.

Multiple contamination was found in 142 chickens (94.6\%), of which 83 (55.3\%) were concurrently contaminated with Campylobacter, Escherichia coli, and Salmonella.

Conclusion: These results show that chickens in Cameroon are highly contaminated with Campylobacter, Escherichia coli, and Salmonella. The multiple contaminations of chickens is a potential risk of infection for consumers and highlights the necessity of public awareness for food safety.
\end{abstract}

Key words: Campylobacter; Escherichia coli; Salmonella; multiple contamination

J Infect Dev Ctries 2010; 4(9):583-586.

(Received 09 March 2010 - Accepted 19 April 2010)

Copyright (C) 2010 Nzouankeu et al. This is an open-access article distributed under the Creative Commons Attribution License, which permits unrestricted use, distribution, and reproduction in any medium, provided the original work is properly cited.

\section{Introduction}

Contaminated, raw, or undercooked poultry products, especially chicken meat, have been shown to be a critical link in transmitting food-borne pathogens to humans, resulting in numerous cases of diseases [1]. Most of these food-borne illnesses are caused by three major bacteria: Campylobacter, Salmonella, and E. coli [2-3]. Infection with these bacteria usually results in a self-limiting gastroenteritis; however, young children, older adults, and the immunocompromised may experience invasive disease [4-5]. Campylobacter has been identified as the predominant cause of GuillainBarre's syndrome and reactive arthritis [6]. E. coli is particularly responsible for different forms of diarrhoea, such as the bloody diarrhoea and hemolytic uremic syndrome caused by $E$. coli O157:H7 [7]. Salmonella is known to be responsible for systemic salmonellosis infections which could be life threatening.
The objective of this study was to evaluate the prevalence of Campylobacter, Escherichia coli, and Salmonella in chickens sold in retail markets in Yaounde, Cameroon to determine the risks associated with the chicken handling and consumption.

\section{Methodology}

Sample collection

Chickens were purchased from eight retail markets in Yaounde. These markets were selected to ensure complete coverage of all the subdivisions of the town. Sampling visits were made once a week from February 2006 to January 2007. The entire chicken carcasses were immediately placed in sterile plastic bags and transported in a cool box to the laboratory, where samples were processed within an hour. 
Table 1. Co-contamination with Campylobacter, E. coli and Salmonella in chickens

\begin{tabular}{|c|c|c|}
\hline Co-infections & Number of contaminated chickens & Total \\
\hline $\begin{array}{l}\text { C. coli }+ \text { E. coli } *+\text { Enteritidis } \\
(\text { C. coli }+ \text { EPEC + Enteritidis })\end{array}$ & $\begin{array}{c}18 \\
2\end{array}$ & 20 \\
\hline $\begin{array}{l}\text { C. coli }+ \text { E. coli }{ }^{*}+\text { Hadar } \\
(\text { C. coli + EPEC + Hadar })\end{array}$ & $\begin{array}{c}12 \\
\mathbf{3}\end{array}$ & 15 \\
\hline $\begin{array}{l}\text { C. } \operatorname{coli}+\text { C. jejuni }+ \text { E. coli }{ }^{*}+\text { Enteritidis } \\
(\text { C. coli }+ \text { C. jejuni }+ \text { EPEC + Enteritidis })\end{array}$ & $\begin{array}{l}9 \\
1\end{array}$ & 10 \\
\hline $\begin{array}{l}\text { C. coli }+ \text { E. coli }{ }^{*}+\text { Salmonella.sp } \\
(\text { C. coli }+ \text { EPEC + Salmonella.sp })\end{array}$ & $\begin{array}{l}7 \\
2\end{array}$ & 9 \\
\hline $\begin{array}{l}\text { C. coli }+ \text { C. jejuni }+ \text { E. coli } *+\text { Salmonella. } S p \\
(\text { C. coli }+ \text { C. jejuni }+ \text { EPEC + Salmonella. } S p)\end{array}$ & $\begin{array}{l}6 \\
1\end{array}$ & 7 \\
\hline $\begin{array}{l}\text { C. coli }+ \text { E. coli } *+\text { Enteritidis +Hadar } \\
(\text { C. coli + EPEC + Enteritidis +Hadar })\end{array}$ & $\begin{array}{l}5 \\
1\end{array}$ & 6 \\
\hline $\begin{array}{l}\text { C. jejuni + E. coli }{ }^{*}+\text { Hadar } \\
(\text { C. jejuni + EPEC + Hadar })\end{array}$ & $\begin{array}{l}5 \\
1\end{array}$ & 6 \\
\hline $\begin{array}{l}\text { C. coli }+ \text { C. jejuni }+ \text { E. coli } * \text { Hadar } \\
(\text { C. coli }+ \text { C. jejuni + EPEC + Hadar })\end{array}$ & $\begin{array}{l}3 \\
1 \\
\end{array}$ & 4 \\
\hline C. jejuni + E. coli* + Salmonella. $s p$ & 4 & 4 \\
\hline $\begin{array}{l}\text { C. jejuni + E. coli }{ }^{*}+\text { Enteritidis } \\
(\text { C. jejuni + EPEC + Enteritidis })\end{array}$ & $\begin{array}{l}1 \\
1 \\
\end{array}$ & 2 \\
\hline Total & 83 & 83 \\
\hline
\end{tabular}

Bacteria isolation and identification

Ten grams of skin from each chicken neck were used for bacterial isolation.

\section{Campylobacter}

Campylobacter were isolated according to the ISO 10272-1 [8] under microaerophillic conditions. Presumptive Campylobacter colonies were confirmed using API CAMPY strips (Biomerieux, Marcyl'Etoile, France).

E. coli

E. coli were cultured following the AFNOR V08053 standard [9] and confirmed with API 20E strips (Biomerieux, Marcy l'étoile, France). Serotyping was performed to detect EPEC (Enterophatogenic E. coli) strains with somatic $\mathrm{O}$, flagellar $\mathrm{H}$ and surface $\mathrm{A}, \mathrm{B}$, $\mathrm{L}$, and $\mathrm{K}$ anti-sera (Bio-Rad Laboratories, Marnes La Coquette, France).

\section{Salmonella}

Salmonella isolation was conducted based on the methods described in the ISO 6579 [10], confirmed with API 20E Strips (Biomerieux, Marcy l'Etoile, France), and serotyped with the somatic $\mathrm{O}$ and flagella H Salmonella anti-sera, according to the Kauffman-White scheme.

\section{Results}

A total of 150 chickens were collected and examined for the presence of Campylobacter, E. coli, and Salmonella. Among them, 135 (90\%) were contaminated with Campylobacter, and 164 Campylobacter strains were isolated $(68.9 \%$ were $C$. coli and $31.1 \% C$. jejuni). Out of 84 chickens that were contaminated with $C$. coli, 29 were contaminated with $C$. coli and $C$. jejuni, while 22 chickens were contaminated with $C$. jejuni alone.

All the chicken carcasses were contaminated with E. coli. Seventeen $(11.3 \%)$ of these strains agglutinated the antisera O 127 B8 (7), O126 B16 (4), O128 B12 (2), O142 K86 (2), O119 B14 (1), and O111 B4 (1). and were reported as enteropathogenic E. coli (EPEC).

A total of 103 Salmonella strains were isolated from 90 chickens (60\%). Seventy-nine chickens were contaminated with only one serotype, ten with two different serotypes and one with four different serotypes. The serotypes obtained were Enteritidis, Hadar, Tilburg, Mikawasima, Bareilly, Cleveland, Colindale, Duesseldorf, Eko, Gwoza, Harburg, Hato, Hiduddify, Liverpool, Manhattan, Muenster, Reading, Saintpaul, and serotype II. The most frequent isolates were Enteritidis (45.6\%) and Hadar (28.1\%) [11]. 
Multiple contaminations with the bacteria genus listed above were obtained in 142 chickens (94.7\%). The eight remaining chickens (5.3\%) were contaminated only with E. coli. Fifty-two chickens (34.7\%) had Campylobacter and E. coli, seven (4.7\%) had E. coli and Salmonella, and 83 (55.3\%) had Campylobacter, E. coli and Salmonella. Table 1 shows the different types of co-infections with these three bacteria together.

\section{Discussion}

Food-borne diseases represent a major public health problem worldwide. This study reveals a high prevalence of Campylobacter, E. coli, and Salmonella in chickens in Yaounde. These bacteria have already been implicated in outbreaks of food poisoning [4]. The high prevalence of Campylobacter $(90 \%)$ in this study corroborates data from several other countries [12-13]. This may be explained by the fact that Campylobacter is commensal in many avian caeca [14]. Cross-transmission of Campylobacter is very high during poultry processing because the chickens are contaminated with their fecal materials [15]. In the present study, $68.9 \%$ of Campylobacter isolates were $C$. coli. Similar results have been obtained in Thailand [16] and South Africa [17]. In most of the cases, $C$. jejuni was the most frequent Campylobacter in poultry [18].

All the chickens purchased for this study were contaminated with $E$. coli. This may be due to the fact that $E$. coli is part of the normal enteric flora of chickens [5]. Among the 150 E. coli strains identified in this work, only $11.3 \%$ were enteropathogenic (EPEC); these strains usually cause diarrhoea in infants (younger than 2 years) through one or more virulence mechanisms [19]. The proportion of EPEC in this study (11.3\%) was lower than that obtained by Farooq et al. in 2009 [20] in which all the E. coli isolated from 25 chickens were EPEC.

The prevalence of Salmonella in chickens in this study was $60 \%$. This is nearly similar to what has been observed in some other developing countries: $68.2 \%$ in Ethiopia [21] and $72 \%$ in Thailand [22]. Enteritidis was the most predominant Salmonella serotype in this study as well as in many others [2324]. Hadar, the second most important serotype $(28.1 \%)$, has also been frequently isolated in chickens [25-26].

The multiple contaminations of many chickens by Campylobacter, E. coli, and Salmonella observed in this study are disturbing. These bacteria, which are dangerous for the young, the old, and the immunocompromised, could be rapidly lifethreatening. This study suggests the importance of monitoring poultry for enteric pathogens in poultry to avoid cross-contamination to humans. Efforts should be made to educate producers, retailers, and consumers on the proper handling and cooking of chicken meat.

\section{Acknowledgments}

This research was supported by the Institut Pasteur International network through ACIP (Action Concertée Inter-Pasteurienne) funding. The authors would like to thank Dr Anfumbon Kfutwah, who helped with English correction.

\section{References}

1. Wilson IG (2002) Salmonella and Campylobacter contamination of raw retail chickens from different producers: a six year survey. Epidemiol Infect 129: 635-645.

2. Todd EC (1997) Epidemiology of foodborne diseases: a worldwide review. World Health Stat 50: 30-50.

3. Meng J, Zhao S, Doyle MP (1998) Virulence genes of Shiga-toxin producing Escherichia coli isolated from food, animals and humans. Int J Food Microbiol 45: 229-235.

4. Sackey BA, Mensah P, Collison E, Sakyi-Dawson E (2000) Campylobacter, Salmonella, Shigella and Escherichia coli in live and dressed poultry from metropolitan Accra. Int $\mathbf{J}$ Food Microbiol. 71: 21-28.

5. Zhao C, Ge B, De Villena J, Sudler R, Yeh E, Zhao S, White DG, Wagner D, Meng J (2001) Prevalence of Campylobacter spp., Escherichia coli, and Salmonella Serovars in Retail Chicken, Turkey, Pork, and Beef from the Greater Washington, D.C., Area. Appl Environ Microbiol 67: 5431-5436.

6. Shane SM (2000) Campylobacter infection of commercial poultry. Rev Sci Tech Off Int Epiz 19: 376-395.

7. Griffin PM (1995) Escherichia coli O157:H7 and other enterohemorrhagic Escherichia coli. In Blaser MJ, Smith PD, Ravdin JI, Greenberg HB, and Guerrant RL, editors. Infections of gastrointestinal tract. New York: Raven Press. 739-761.

8. ISO 10272-1 (2006) Microbiology of food and animal feeding stuffs. Horizontal method for detection and enumeration of Campylobacter spp. Part 1: Detection method. International Organization for Standardization.

9. AFNOR. (2002). NF V08-053 - Microbiology of food and animal feeding stuffs - Horizontal method for the enumeration of beta-glucuronidase positive Escherichia coli using 5-bromo-4-chloro-3-indolyl beta-D-glucuronide by colony count technique at $44^{\circ} \mathrm{C}$-Routine method.

10. ISO 6579 (2002) Microbiology of food and animal feeding stuffs. Horizontal method for detection of Salmonella spp. 4th edition. International Organization for Standardization.

11. Wouafo M, Nzouankeu A, Kinfack JA, Fonkoua M-C, Ejenguele G, Njine T, Ngandjio A. Prevalence and Antimicrobial Resistance of Salmonella Serotypes in Chickens from Retail Markets in Yaounde (Cameroon). Microb Drug resist. In press.

12. Ledergerber U, Regula G, Stephan R, Danuser J, Bissig B, Stärk KDC (2003) Risk factors for antibiotic resistance in Campylobacter spp. Isolated from raw poultry meat in Switzerland. BMC Public Health 3: 39-48. 
13. Denis M, Refrégier-Petton J, Laisney M-J, Ermel G, Salvat G (2001) Campylobacter contamination in French chicken production from farm to consumers. Use of a PCR assay for detection and identification of Campylobacter jejuni and Campylobacter coli. J Appl Microbiol 91: 225-267.

14. Keener KM, Bashor MP, Curtis PA, Sheldon BW, Kathariou S (2004) Comprehensive Review of Campylobacter and Poultry Processing. Compr Rev Food Sci Food Saf 3: 105116.

15. Pacheco K, Peña Y, Gamboa MM, Hernánd F (1999) Prevalence of Campylobacter in chickens in a tropical environment. Rev Biomed 10: 63-64.

16. Padungtod P, Kaneene JB (2005) Campylobacter in food animals and humans in northern Thailand. J Food Prot 68: 2519-2526.

17. van Nierop W, Dusé AG, Marais E, Aithma N, Thothobolo N, KasselM, Stewart R, Potgieter A, Fernandes B, Galpin JS, Bloomfield SF (2005) Contamination of chicken carcasses in Gauteng, South Africa, by Salmonella, Listeria monocytogenes and Campylobacter. Int J Food Microbiol 99: 1-6.

18. Suzuki H, Yamamoto S (2009) Campylobacter Contamination in Retail Poultry Meats and By-Products in the World: A Literature Survey. J Vet Med Sci 71: 255-261.

19. Levine MM, Edelman R (1984) Enteropathogenic Escherichia coli of classic serotypes associated with infant diarrhea: epidemiology and pathogenesis. Epidemiol Rev 6: 31-51.

20. Farooq S, Hussain I, Mir M.A, Bhat MA, Wani SA (2009) Isolation of atypical enteropathogenic Escherichia coli and Shiga toxin 1 and 2 producing Escherichia coli from avian species in India. Lett Appl Microbiol 48: 692-697.

21. Tibaijuka B, Molla B, Hildebrandt G, Kleer J (2003) Occurrence of Salmonellae in retail raw chicken products in Ethiopia. Berl Munch Tierarztl Wochenschr 116: 55-58.
22. Boonmar S, Bangtrakulnonth A, Pornrunangwong S, Marnrim N, Kaneko K, Ogawa M (1998) Predominant serovars of Salmonella in humans and foods from Thailand. J Vet Med Sci 60: 877-880.

23. Goncagül G, Günaydin E, Carli TK (2005) Prevalence of Salmonella serogroups in chicken meat. Turk J Vet Anim Sci 29: 103-106.

24. Al-Zenki S, Nasser A, Al-Safar A, Alomirah H, Al-Haddad A, Hendriksen RS, Aarestrup FM (2007) Prevalence and antibiotic resistance of Salmonella isolated from poultry farm and processing plant in the environment in the state of Kuwait. Foodborne Pathog Dis 4: 367-373.

25. Cardinale E, Gros-Claude JDP, Tall F, Cisse EF, Gueye EF, Salvat G (2003) Prevalence of Salmonella and Campylobacter in retail chicken carcasses in Senegal. Rev Elev Med Vet Pays Trop 56: 13-16.

26. Capita R, Alonso-Calleja C, Prieto M (2007) Prevalence of Salmonella enterica serovars and genovars from chicken carcasses in slaughterhouses in Spain. J Appl Microbiol 103: $1366-1375$

\section{Corresponding author}

Ndayo Wouafo Marguerite

Pasteur Centre of Cameroon

Laboratory of Hygiene and Environment - Microbiology

PO Box 1274

Yaounde, Cameroon

Tel: +23722231803 / +237 77477362

Fax: +2372223 1564

Email: wouafo@pasteur-yaounde.org

Conflict of interests: No conflict of interests is declared. 